\title{
Canola seed germination and seedling initial growth under conditions of salinity
}

\section{Germinação e crescimento inicial de plântulas de canola em condições de salinidade}

\author{
Vanessa Neumann SILVA²; Joseani da Silveira TALHAFERRO ${ }^{1,3}$ \\ ${ }^{1}$ Trabalho de pesquisa realizado na Universidade Federal do Pampa referente ao trabalho de iniciação científica. \\ ${ }^{2}$ Doutora em Fitotecnia, Professora Adjunta, Universidade Federal do Pampa, vnpel@yahoo.com.br. Autora para \\ correspondência: Universidade Federal do Pampa, Rua Luiz Joaquim de Sá Britto, s/n, Bairro Promorar, Itaqui- \\ RS, 97650-000, vnpel@yahoo.com.br \\ ${ }^{3}$ Acadêmica do curso de Agronomia, Universidade Federal do Pampa, josistalhaferro@hotmail.com
}

Recebido em: 28-12-2013; Aceito em: 05-05-2014

\begin{abstract}
An environmental factor that limits crop productivity is referred to as a stress. Salinity in soil or in water is one of major stresses and can severely limit crop production. The genus Brassica involves a considerable number of economical and nutritional valuable crops. All those species are sensitive to salinity conditions. Germination is the most critical period for a crop subjected to salinity. The objective of this study was to evaluate canola seed germination and seedling growth under conditions of salinity. Canola seeds of the cultivars Hyola 61 and Hyola 433 were submitted to conditions of $0,0.1$, $0.15,0.2$, and $0.25 \mathrm{~mol} \mathrm{~L}^{-1}$ of $\mathrm{NaCl}$ during a germination test under the temperature of $20{ }^{\circ} \mathrm{C}$ for 7 days. Seed germination counting was performed five and seven days after sowing. The experiment was set according to a completely random design with four repetitions. Seed quality factor (cultivar) means were compared by the Tukey's test whereas for those of the quantitative factor (salinity levels) regression equations were adjusted. Salinity resulting from $\mathrm{NaCl}$ reduces canola seed germination with more expressive effects at $0,25 \mathrm{~mol} \mathrm{~L}^{-1}$ and seedling root and shoot growth. The most sensitive cultivar to salinity was Hyola 61.
\end{abstract}

Additional keywords: Brassica napus var. oleifera; sodium chloride; stress.

\section{Resumo}

Um fator ambiental que limita a produtividade das culturas é conhecido como estresse. A salinidade no solo ou água é um dos maiores estresses que podem limitar seriamente a produção de culturas. A germinação é o período mais crítico para uma cultura ser exposta a estresse salino. O gênero Brassica envolve um considerável número de culturas com valor econômico e nutricional, mas seu crescimento, produtividade e produção de óleo são extremamente reduzidos pela salinidade. Objetivou-se avaliar a germinação e o crescimento inicial em plântulas de canola submetidas a diferentes níveis de salinidade. Utilizaram-se sementes de canola das cultivares Hyola 61 e Hyola 433, submetidas ao teste de germinação com níveis de salinidade de 0 (controle), 0,1;0,15;0,2 e $0,25 \mathrm{~mol} \mathrm{~L}^{-1}$ de $\mathrm{NaCl}$, a $20^{\circ} \mathrm{C}$, por sete dias. As contagens de germinação foram realizadas aos cinco e sete dias após a semeadura. O crescimento inicial de plântulas foi avaliado por meio do comprimento de raiz e parte aérea, mensurado aos sete dias após a semeadura. $O$ delineamento experimental utilizado foi o completamente casualizado, com quatro repetições, em esquema fatorial $2 \times 5$ (-cultivares $\times$ níveis salinidade). Os resultados foram submetidos à análise de variância e comparação de médias, pelo teste de Tukey, a $5 \%$ de probabilidade para o fator qualitativo (cultivares), e para o fator quantitativo (níveis de salinidade) foram ajustadas equações de regressão. A salinidade causada pelo cloreto de sódio diminui a germinação e o crescimento de raiz e parte aérea de plântulas, com efeito mais expressivo em concentração de $0.25 \mathrm{~mol} \mathrm{~L}^{-1}$, sendo a cultivar Hyola 61 mais sensível.

Palavras-chave adicionais: Brassica napus var. oleifera; cloreto de sódio; estresse. 


\section{Introduction}

Canola oil is now the third largest source of edible oil following soybean and palm oil (CANOLA COUNCIL of CANADA, 2013). This increased demand will undoubtedly promote increased acreage of canola in the world where some soils are prone to become saline (FRANCOIS, 1994). According to Tomm (2007) salinity may be a problem to canola seedling establishment

Plants growing under field conditions are exposed to various environmental factors; any deviation in these factors from the optimum levels is deleterious to plants and leads to stress. Stress may be caused due to abiotic factors like high temperature, cold, drought, salinity, or the biotic factors like viruses, insects, nematodes, bacteria, fungi etc. At a given point of time, plant may have to face even a combination of more than one of above mentioned factors. However, amongst these stresses, salinity has emerged as one of the most serious factors limiting productivity of agricultural crops (PURTY et al., 2008).

Germination is the most critical period for a crop subjected to salinity. Germination failures under saline soils are often the results of high salt concentrations in the seed planting zone because of upward movement of soil solution and subsequent evaporation at the soil surface (BERNSTEIN, 1974). Seed germination has been reported to decline with increasing salinity levels (HOULE et al., 2001).

According to Al-Thabet et al. (2004) canola seed germination (percentage and speed) decreased with increasing salinity concentration levels beyond $0.1 \mathrm{~mol} \mathrm{~L}^{-1}$ using $\mathrm{NaCl}$ as salinity source for cultivars Al-Serw4, Al-Serw 8 and Pactol. Although, for the majority of cultivars there is a lack of information about salinity effects on seed germination and seedling growth.

The objective of this work was to evaluate the effects of sodium chloride salinity levels on canola seed germination and seedling growth.

\section{Materials and methods}

The experiment was carried out at with Canola cultivars Hyola 61 and Hyola 433. Seeds were exposed to salinity levels and evaluated as germination and seedling growth tests, as follows.

Germination: four replications of 50 seeds, per treatment, were submitted to germination test at $20{ }^{\circ} \mathrm{C}$ according to a totally randomized design. These seeds germinated on papers for germination test imbibed in distilled water (control) or in sodium chloride $(\mathrm{NaCl})$ solutions at a proportion of 2.5 times the weight of the paper. The $\mathrm{NaCl}$ concentrations used were 0.1 , $0.15,0.20$ and $0.25 \mathrm{~mol} \mathrm{~L}^{-1}$. The evaluations were carried out according to the Rules for Seed Analysis (BRASIL, 2009) at the first and second count, after five and seven days and the data were assessed for percentage of normal seedlings.

Growth seedling tests: after germination evaluations, 20 normal seedlings were randomly selected and evaluated as shoot length (SL) and root length (RL) (NAKAGAWA, 1999).

The experimental design used was a completely randomized with four replications, in a $2 \times 5$ factorial scheme (cultivars $x$ salinity levels). Data of qualitative factor (cultivar) were statistically analyzed for means comparison using the Tukey test $(p<0.05)$ and for the quantitative factor (salinity levels) regressions equations were adjusted.

\section{Results and discussion}

The percentage of normal seedlings at the first count germination was reduced as salinity levels increased, with more expressive effects on Hyola 61 cultivar (Table 1 and Figure 1). Doses up to 0.18 and $0.19 \mathrm{~mol} \mathrm{~L}^{-1}$ of $\mathrm{NaCl}$, for Hyola 61 and Hyola 433, respectively, caused extremely negative effects on seed germination, as show in Figure 1.

The total germination percentage was reduced linearly in all salinity levels in both cultivars, and at $0.25 \mathrm{~mol} \mathrm{~L}^{-1}$ germination capacity was almost completely inhibit (Table 1 and Figure 1). Also, were found close relationship between increase in salinity levels and percentage of abnormal seedlings, as doses up to $0.08 \mathrm{~mol} \mathrm{~L}^{-1}$ of $\mathrm{NaCl}$ caused high abnormal seedlings percentage for Hyola 61 and for Hyola 433 was observed a linear increase. Al-Thabet et al. (2004) found that canola seed germination percentage and germination speed decreased with increasing salinity concentration levels beyond $0.1 \mathrm{~mol} \mathrm{~L}^{-1}$ using $\mathrm{NaCl}$ as salinity source and correlated these results with osmotic effects.

Changes in osmotic potential may reduce seed water uptake and causes negative effects on seed germination, considering that water is essential for seed storage reserves digestion and for all germination phases (BEWLEY et al., 2013). Besides osmotic stress, salinity is responsible for the induction of primary effects like ionic stress which in turn induce oxidative stress in plants (AHMAD et al., 2012). Reactive oxygen species (ROS) generated as a result of oxidative stress is highly deleterious for plants. ROS can destroy the structure and functions of biomolecules such as membrane lipids, proteins and nucleic acids (HERNANDEZ et al., 2001; AHMAD et al., 2010) and in higher concentrations, causes death of the plant cells (AHMAD and SHARMA, 2008; AHMAD 
et al., 2010). Also, salinity causes ion cytotoxicity by the replacement of $\mathrm{K}^{+}$by $\mathrm{Na}^{+}$in biochemical reactions and by the loss of function of proteins, as $\mathrm{Na}^{+}$and $\mathrm{Cl}^{-}$ions penetrate the hydration shells and interfere with the non-covalent interaction among the amino acids (ZHU, 2002).

As similar to germination results, seedling growth was reduced as salinity levels increased, in both cultivars (Figure 2 and Table 1). Seedling shoot length was decreased linearly for both cultivars with increases in salinity levels, as root length was at doses up to $0.2 \mathrm{~mol} \mathrm{~L}^{-1}$ of $\mathrm{NaCl}$.

Similar results were found by Bybordi and Tabatabei (2009); these authors verified that when salinity levels increased canola seedling length and fresh dry seedling mass reduces.
Naim et al. (2012) found that sorghum seedlings growth was reduced at the higher salt concentrations (4, 8 and $16 \mathrm{dS} / \mathrm{m}$, caused by 2.10, 4.95 and $9.9 \mathrm{~g} \mathrm{NaCl} \mathrm{L}^{-1}$ ). Studying cell and plant responses to $\mathrm{NaCl}$ in corn Mansour et al. (2005) concluded that $\mathrm{NaCl}$ increased plasm membrane permeability. Also, salt stress induces cellular accumulation of damaging active oxygen species that can damage membrane lipids and proteins (MITTLER, 2002). Changing membrane permeability can lead to solute leaching, reducing mitochondrial efficiency as for consequence ATP production and energy for seed germination (NONOGAKI et al., 2010) and seedling growth.


Figure 1 - Germination, germination first count, abnormal seedlings of canola seeds, cultivars Hyola 433 (A) and Hyola 61 (B) submitted to different levels of salinity. 
Table 1 - First count germination, germination, abnormal seedlings, seedling shoot length and root length of canola seeds, cultivars Hyola 61 and Hyola 433, submitted to different levels of salinity.

\begin{tabular}{|c|c|c|c|c|c|}
\hline \multirow[t]{3}{*}{ Cultivar } & \multicolumn{5}{|c|}{ Salinity levels ( $\left.\mathrm{mol} \mathrm{L}^{-1} \mathrm{NaCl}\right)$} \\
\hline & 0 & 0,1 & 0,15 & 0,20 & 0,25 \\
\hline & \multicolumn{5}{|c|}{ First Count Germination (\%) } \\
\hline $\begin{array}{l}\text { Hyola } 61 \\
\text { Hyola } 433\end{array}$ & $\begin{array}{l}48 \mathrm{Ba}^{*} \\
84 \mathrm{Aa}\end{array}$ & $\begin{array}{l}6 \mathrm{Ab} \\
5 \mathrm{Ab}\end{array}$ & $\begin{array}{l}1 \mathrm{Ab} \\
0 \mathrm{Ab}\end{array}$ & $\begin{array}{l}0 \mathrm{Ab} \\
0 \mathrm{Ab}\end{array}$ & $\begin{array}{l}0 \mathrm{Ab} \\
0 \mathrm{Ab}\end{array}$ \\
\hline \multirow[t]{2}{*}{$\mathrm{CV}(\%)$} & & & 18 & & \\
\hline & \multicolumn{5}{|c|}{ Germination (\%) } \\
\hline $\begin{array}{l}\text { Hyola } 61 \\
\text { Hyola } 433\end{array}$ & $\begin{array}{l}76 \mathrm{Aa} \\
84 \mathrm{Aa}\end{array}$ & $\begin{array}{l}56 \mathrm{Ab} \\
52 \mathrm{Ab}\end{array}$ & $\begin{array}{l}37 \mathrm{Ac} \\
41 \mathrm{Ac}\end{array}$ & $\begin{array}{l}14 \mathrm{Bd} \\
27 \mathrm{Ad}\end{array}$ & $\begin{array}{l}4 \mathrm{Ae} \\
0 \mathrm{Be}\end{array}$ \\
\hline \multirow[t]{2}{*}{$\mathrm{CV}(\%)$} & \multicolumn{5}{|c|}{26} \\
\hline & \multicolumn{5}{|c|}{ Abnormal Seedlings (\%) } \\
\hline $\begin{array}{l}\text { Hyola } 61 \\
\text { Hyola } 433\end{array}$ & $\begin{array}{c}16 \mathrm{Aa} \\
9 \mathrm{Aa}\end{array}$ & $\begin{array}{c}33 \mathrm{Bb} \\
8 \mathrm{Aa}\end{array}$ & $\begin{array}{l}48 \mathrm{Bc} \\
9 \mathrm{Aa}\end{array}$ & $\begin{array}{l}44 \mathrm{Bc} \\
10 \mathrm{Aa}\end{array}$ & $\begin{array}{l}65 \mathrm{Bd} \\
15 \mathrm{Ab}\end{array}$ \\
\hline \multirow[t]{2}{*}{$\mathrm{CV}(\%)$} & & & 20 & & \\
\hline & \multicolumn{5}{|c|}{ Shoot Lenght $(\mathrm{cm})$} \\
\hline $\begin{array}{l}\text { Hyola } 61 \\
\text { Hyola } 433\end{array}$ & $\begin{array}{l}2,5 \mathrm{Aa} \\
2,8 \mathrm{Aa}\end{array}$ & $\begin{array}{l}2,1 \mathrm{Aa} \\
2,1 \mathrm{Ab}\end{array}$ & $\begin{array}{l}1,5 \mathrm{Ab} \\
1,3 \mathrm{Aa}\end{array}$ & $\begin{array}{l}1,2 \mathrm{Ab} \\
1,2 \mathrm{Aa}\end{array}$ & $\begin{array}{l}0,9 \mathrm{Ac} \\
1,0 \mathrm{Aa}\end{array}$ \\
\hline \multirow[t]{2}{*}{$\mathrm{CV}(\%)$} & & & 18 & & \\
\hline & \multicolumn{5}{|c|}{ Root Lenght (cm) } \\
\hline $\begin{array}{l}\text { Hyola } 61 \\
\text { Hyola } 433\end{array}$ & $\begin{array}{l}2,7 \mathrm{Aa} \\
2,3 \mathrm{Aa}\end{array}$ & $\begin{array}{l}1,1 \mathrm{Ab} \\
1,3 \mathrm{Ab}\end{array}$ & $\begin{array}{l}0,9 \mathrm{Ab} \\
0,8 \mathrm{Ac}\end{array}$ & $\begin{array}{l}0,7 \mathrm{Ac} \\
0,9 \mathrm{Ac}\end{array}$ & $\begin{array}{l}0,8 \mathrm{Ab} \\
0,9 \mathrm{Ac}\end{array}$ \\
\hline CV(\%) & \multicolumn{5}{|c|}{20} \\
\hline
\end{tabular}

*Averages follow the same capital letter in column and small letter in line not differ at Tukey's test $(p<0,05)$.
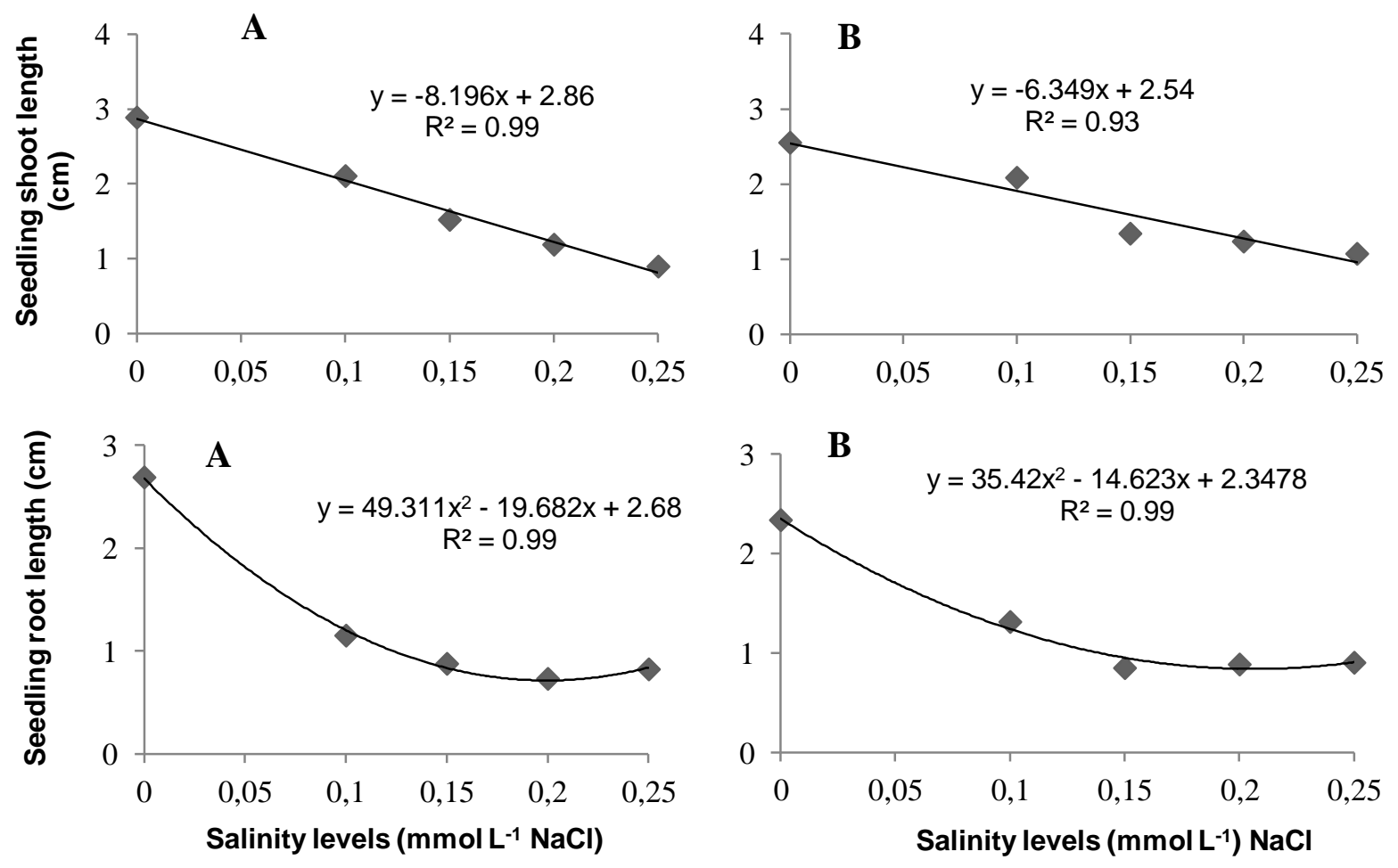

Figure 2 - Canola cultivars Hyola 433 (A) and Hyola 61 (B) seedlings shoot and root length as influenced by different levels of salinity. 
Besides, according to Neumann (1997) high intracellular concentrations of $\mathrm{Na}^{+}$and $\mathrm{Cl}^{-}$ can inhibit the metabolism of dividing and expanding cells. Considering that high salinity levels decreasing protein synthesis and lipid metabolism (GEISSLER et al., 2009) and these are the major reserves sources in canola seeds, because typically canola seed has an oil content ranging from $35-45 \%$ and a minimum of $35 \%$ protein (AOF, 2007), probably, this cause negative effects on seedling growth because the energy available for this process is reduced.

Is important also to highlight that in plant cells, toxicity is resolved by vacuolar compartmentalization (QIU et al., 2007), and recent reports suggest that $\mathrm{Na}^{+}$can be bound in starch granules (KANAl et al., 2007), although, this compartmentalization would be energy intensive, while binding sodium to starch would prevent the starch from being used to provide energy for germination (ZHANG et al., 2010) as for seedling growth.

\section{Conclusion}

Salinity caused by $\mathrm{NaCl}$ reduces canola seed germination, with more expressive effects at $0.25 \mathrm{~mol} \mathrm{~L}^{-1}$ level and seedling root and shoot growth; Hyola 433 was the cultivar more sensitive to salinity stress.

\section{References}

AHMAD, P.; SHARMA, S. Salt stress and phytobiochemical responses of plants. Plant Soil Environment, Praha, v.54, n.1, p.89-99, 2008.

AHMAD, P.; NABI, G.; UMAR, S.; SHARMA, S. Mechanism of free radical scavenging and role of phytohormones during abiotic stress in plants. In: ASHRAF, M.; OZTURK, M., AHMAD, M.S.A. (Ed.). Plant adaptation and phytoremediation. New York: Springer, 2010. p.99-118.

AHMAD, P.; HAKEEM, K. R.; KUMAR, A.; ASHRAF, M.; AKRAM, M. A. Salt-induced changes in photosynthetic activity and oxidative defense system of three cultivars of mustard (Brassica juncea L.). African Journal of Biotechnology, v.11, n.11, p.2694-2703, 2012.

AL-THABET, S. S.; LEILAH, A. A.; AL-HAWASS, I. Effect of $\mathrm{NaCl}$ and incubation temperature on seed germination of three canola (Brassica napus L.) cultivars. Scientific Journal of King Faisal University, Riyadh, v.5, n.1, p.81-94, 2004.

AOF. Australian canola meal guide for seed industry. 2007. Disponível em: $<$ <ttp://www.australianoilseeds.com/protein_meal>
BERNSTEIN, L. Crop growth and salinity. In: van SCHIFFGAARDE, J. (Ed.). Drainage for agriculture. Madison: ASA, 1974. p.39-54. (Agron. Monogr, 17).

BEWLEY, J. D.; BRADFORD, K. J.; HILHORST, H. W. M.; NONOGAKI, H. Seeds: physiology of development, germination and dormancy. $3^{\text {rd }}$ ed. New York: Springer, 2013.

BRASIL. Ministério da Agricultura, Pecuária e Abastecimento. Secretaria de Defesa Agropecuária. Rules for seed testing. Brasília, DF: Mapa/ ACS, 2009.

BYBORDI, A.; TABATABAEI, J. Effect of salinity stress on germination and seedling properties in canola cultivars (Brassica napus L.). Notulae Botanicae Horti Agrobotanici, Cluj-Napoca, v.37, n.2, p.71-76, 2009.

CANOLA COUNCIL OF CANADA. Cereals \& oilseeds review - statistics Canada \& Canadian Grain Commission. Disponível em: <http://www.canola-council.org/currseedexp.aspx>. Acesso: 15 sept. 2013.

FRANCOIS, L. E. Growth, seed yield, and oil content of canola grown under saline conditions. Agronomy Journal, Madison, v.86, n.2, p.233237, 1994.

GEISSLER, N.; HUSSIN, S.; KOYRO, H. W. Interactive effects of $\mathrm{NaCl}$ salinity and elevated atmospheric $\mathrm{CO}_{2}$ concentration on growth, photosynthesis, water relations and chemical composition of the potential cash crop halophyte Aster tripolium L. Environmental Experimental Botany, Elmsford, v.65, n.2-3, p.220-231, 2009.

HERNANDEZ, J. A.; FERRER, M. A.; JIMENEZ, A.; BARCELO, A. R.; SEVILLA, F. Antioxidant systems and $\mathrm{O}^{-} / \mathrm{H}_{2} \mathrm{O}_{2}$ production in the apoplast of pea leaves. Its relation with salt-induced necrotic lesions in minor veins. Plant Physiology, Rockville, v.127, n.3, p.817-831, 2001.

HOULE, G.; MOREL, G.; REYNOLDS, C. E.; SIEGEL, J. The effect of salinity on different developmental stages of an endemic annual plant, Aster laurentianus (Asteraceae). American Journal of Botany, Columbus, v.88, n.1, p.62-67, 2001.

KANAI, M.; HIGUCHI, K.; HAGIHARA, T.; ISHII, T.; FUJITA, N.; NAKAMURA, Y.; MAEDA, Y.; YOSHIBA, M.; TADANO, T. Common reed produces starch granules at the shoot base in response to salt stress. New Phytologist, Cambridge, v.176, n.3, p.572- 580, 2007. 
MANSOUR, M. M. F; SALAMA, K. H. A.; ALI, F. Z. M.; HADID, A. F. A. Cell and plant responses to $\mathrm{NaCl}$ in Zea mays L. cultivars differing in salt tolerance. Genetic Applyed Plant Physiology, Sofia, v.31, n.1-2, p.29-41, 2005.

MITTLER, R. Oxidative stress, antioxidants and stress tolerance. Trends Plant Science, Cambridge, v.7, p.405-410, 2002.

NAIM, A. M. E.; MOHAMMED, K. E.; IBRAHIM, E. A.; SULEIMAN, N. N. Impact of Salinity on seed germination and early seedling growth of three sorghum (Sorghum bicolor L. Moench) cultivars. Science and Technology, Sweden, v.2, n.2, p.16-20, 2012.

NEUMANN P. Salinity resistance and plant growth revisited. Plant Cell and Environment, Oxford, v.20, n.9, p.1193-1198, 1997.

NAKAGAWA, J. Seed vigor tests based in seedling evaluation. In: KRZYZANOWSKI, F. C.; VIEIRA, R. D.; FRANÇA-NETO, J. B. (Ed.). Seed vigor: concepts and tests. Londrina: ABRATES, 1999. p.2:1- 2:21, 1999.

NONOGAKI, H.; BASSEL, G. W.; BEWLEY, J. D. Germination-Still a mystery. Plant Science, Limerick, v.179, p.574-581, 2010.
PURTY, R. S.; KUMAR, G.; SINGLA-PAREEK, S. L.; PAREEK, A. Towards salinity tolerance in Brassica: an overview. Physiology Molecular Biology Plants, Lucknow, v.14, n.1 e 2, p.39-49, 2008.

QIU, N. W.; CHEN, M.; GUO, J. R.; BAO, H. Y.; MA, X. L., WANG, B. S. Coordinate up-regulation of $\mathrm{V}-\mathrm{H}+-A T P a s e$ and vacuolar $\mathrm{Na}+/ \mathrm{H}_{+}$antiporter as a response to $\mathrm{NaCl}$ treatment in $\mathrm{a}_{3}$ halophyte Suaeda salsa. Plant Science, Limerick, v.172, n.6, p.1218-1225, 2008.

TOMM, G. Indicativos tecnológicos para a produção de canola no Rio Grande do Sul .Passo Fundo: Embrapa Trigo, 2007. 68p.

ZHANG, H.; IRVING, L. J.; M CGILL, C.; MATTHEW, C.; ZHOU, D.; KEMP, P. The effects of salinity and osmotic stress on barley germination rate: sodium as an osmotic regulator. Annals of Botany, London, v.106, n.6, p.1027-1035, 2010.

ZHU, J.K. Salt and drought stress signal transduction in plants. Annual Review Plant Biology, Palo Alto, v.53, n.1, p.247-273, 2002. 